\title{
Kaliningrad oblast in the military system of the Russian Federation
}

\author{
Marek Żyła ${ }^{1}$, \\ ${ }^{1}$ War Studies University, Warsaw, Poland
}

\begin{abstract}
From the geopolitical point of view, the Kaliningrad Oblast, due to its exclave location, has become an area of strategic importance. Its strategic nature has been steadily increasing with the successive enlargements of the European Union and NATO. The geographical location and the army stationed in the area allow Moscow to control the situation in the Baltic Sea basin. This makes it possible, through the Euro-Atlantic location of most countries in the region, to influence European policies. In this way, Russia is playing a leading role in this part of the continent. From the point of view of the countries within the region, it is a global military power and a regional superpower. In this context, Kaliningrad exclave increasingly more frequently serves as a security policy tool. It is part of the ongoing threat to the Baltic States and Poland. Demilitarisation of the region, which is periodically demanded by neighbouring countries, is impossible for several reasons. The armed forces stationed there are a counterbalance to the expanding North Atlantic Treaty Organisation from Russia's point of view. They serve to protect national interests and secure the affairs of the Russian and Russian-speaking diasporas in the immediate vicinity. They protect the Russian economic zone and access to the resources of the Baltic Sea. Moreover, the military potential located in the Kaliningrad Oblast, since the collapse of the Soviet Union, has been a guarantee of continuity of Potsdam's border solutions.
\end{abstract}

Keywords: Kaliningrad Oblast, geopolitical location, structure and tasks of the armed forces, training

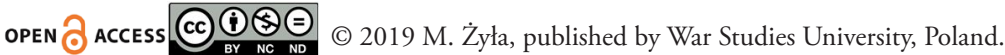

This work is licensed under the Creative Commons Attribution-NonCommercial-NoDerivatives 4.0 License. 


\section{Introduction}

The lands currently belonging to the Kaliningrad Oblast, in the past centuries, were of interest to the neighbours who sought to acquire them. The political and military location of the region and the natural conditions which favour the development of defence infrastructure were appreciated. Due to historical circumstances and frequent changes in political subordination, many countries have claimed rights to them. After the end of the Second World War, the Russian state appeared in a part of the area where it has never functioned before. After the collapse of the Union of Soviet Socialist Republics, the region became an exclave of Russia. It is separated from the main part of the territory of the Russian Federation by the former federal republics, some of which joined the Euro-Atlantic security area after independence.

From the geopolitical point of view, the Kaliningrad Oblast, due to its exclave location, has become an area of strategic importance. Its strategic nature is steadily increasing with the successive enlargements of the EU and NATO. The geographical location and with its army stationed in the area allow Moscow to control the situation in the Baltic Sea Region. This makes it possible, through the Euro-Atlantic membership of most countries in the region, to influence European policies. In this way, Russia is playing a leading role in this part of the continent. From the point of view of the countries of the region, it is a global military power and a regional superpower. In this context, the Kaliningrad exclave increasingly serves as a security policy tool. It is part of an ongoing threat to the Baltic States and Poland. Demilitarisation of the Oblast, which is periodically demanded by neighbouring countries, is impossible for several reasons. The armed forces stationed there are a counterbalance to the expanding North Atlantic Alliance from Russia's point of view. They serve to protect national interests and secure the interests of the Russian and Russian-speaking diasporas in the immediate vicinity. They protect the Russian economic zone and access to the resources of the Baltic Sea. Moreover, the military potential located in the Kaliningrad Oblast since the break-up of the Soviet Union has been a guarantee of the continuity of Potsdam's border delineations. 


\section{Geopolitical location}

The Kaliningrad Oblast covers 13,404 km, and 15,096 km together with parts of the Vistula (Kaliningrad) and Curonian lagoons belonging to the Russian Federation (Skrzyp and Lach 1997, p. 6). This gives $0.088 \%$ of its total area. It is 4 times smaller than Lithuania and 21 times smaller than Poland. In terms of distance, it is closest to Vilnius which is only $350 \mathrm{~km}$ from the capital city of the Oblast. -. The distances to the capitals of other neighbouring countries are respectively: Riga $-390 \mathrm{~km}$, Warsaw $-400 \mathrm{~km}$, Berlin $-600 \mathrm{~km}$ and Stockholm $-650 \mathrm{~km}$. The distance from Kaliningrad to Moscow is $1290 \mathrm{~km}$. After the collapse of the Soviet Union and the regaining of independence by the Baltic republics, the Kaliningrad exclave became the westernmost territory of Russia. The Kaliningrad Oblast borders Poland in the south and Lithuania in the east and north. Its western border is the Baltic Sea, the Vistula Spit and the Curonian Spit. Its longitudinal extent is about $200 \mathrm{~km}$ and its latitudinal extent is $110 \mathrm{~km}$. The length of the sea coast is $150 \mathrm{~km}$, and the land border with Lithuania is $303 \mathrm{~km}$ and $218 \mathrm{~km}$ with Poland. The perimeter of the Oblast and its site index ${ }^{1}$ validate its favourable location. In terms of protection and defence, the geographical diversity requires all types of armed forces to be stationed on its territory. The relatively small area of the exclave does not provide an adequate strategic depth.

The territory of today's Kaliningrad Oblast has played an important geopolitical role. It was of interest to the neighbouring countries, especially Sweden, Russia (later the USSR), Germany and Poland. These countries, appreciating its geopolitical importance, sought to extend their influence to the region, as control of the Oblast facilitated the exercise of control over the Baltic Sea. Until the end of World War II, Kaliningrad was part of East Prussia, which was seen as the cradle of a modern German state. It was identified with the symbolism of the German tradition of the great powers. It constituted a strategic area in the German eastern policy (Eberhardt 1996, p. 17). Reaching for Nieman, it posed a military threat to neighbouring countries. It allowed Germans to politically penetrate its eastern neighbours. During the last world war, it played a very important military role. Among other things, it was used to provide permanent protection of access paths to the central parts of Germany. East Prussia

1 Site index (optimisation) - of border delineation. The shorter (i.e. resembling the circumference of a circle) the borderlines are, the easier it is to defend them, i.e. 
played a key role as a place of military concentration in the campaigns against Poland in 1939 and against the Soviet Union in 1941. During World War II, the Allies returned to the idea proposed after the end of the previous world conflict, consisting in liquidation of the province and including its lands in the composition of the neighbouring countries. The Soviet Union, having no historical arguments for the incorporation of a part of this territory, based its claims on a geopolitical calculation (Palmowski 2013, p. 72). The Soviet authorities, for the first time, presented official expectations in relation to East Prussia at a conference in Tehran in 1943 (Sawicki 2013, p. 116). The decision to liquidate and partition the German province, which was finally made at the conference, did not raise any doubts (Eberhardt 1994, pp. 695-696).

The acquisition of a part of East Prussia was of great strategic importance for the Soviet Union. The area included large sea ports with extensive coastal and logistic infrastructure, whose additional advantage was the fact that they did not freeze during the winter. They made it possible to control the entire water body of the Baltic Sea. The territory of the former East Prussia was notable for its good communications infrastructure and extensive military infrastructure, which allowed for the stationing of significant numbers of military groups. The incorporation of Kaliningrad enabled the Soviet Union to strengthen its influence in Europe, particularly in its central part. The years of the Cold War made Central Europe a kind of buffer, a security zone, a kind of foreground, which was to protect the USSR from a possible invasion and to constitute an element of threat to Western Europe. This order was guarded, among other things, by the military potential vested in the Kaliningrad Oblast.

The strategic importance of the region increased after the collapse of the Soviet Union. After the Baltic republics regained independence and Belarus gained independence, the Kaliningrad exclave became the westernmost area of Russia. Due to its geographical location, which is of significant strategic value from a military point of view, and geophysical conditions conducive to the stationing of all types of armed forces, it is of key importance for the foreign and security policy of the Russian Federation. The importance of this area is growing significantly, considering that Russia lost most of its military infrastructure in Europe after the collapse of the USSR. The region enables the control of the Baltic Sea area as well as having a political and military impact on the neighbouring countries. The location of the Kaliningrad exclave and its military potential give Moscow the opportunity to influence the development of the situation in the whole region and 
of European policy in general. Russia continues to play a leading role in Europe thanks to its co-shaping of the situation around Kaliningrad (at the junction of NATO's and the EU's eastern borders).

\section{Military conditions}

The Soviet Union saw the territory west of its borders as an area of strategic importance. East Prussia was particularly important in this context. For centuries, they had been the axis of one of the main operational directions of activities in Eastern Europe. During the Yalta-Potsdam period, control over a part of the region was one of the conditions for the Soviet Union to maintain its influence in Europe. The division of Prussia established the domination of the USSR in this part of the continent and provided a good position for military expansion to the West (Wrzesiński 1992, p. 52). This objective was being carried out, among others, by militarisation of the area and establishment of the Baltic Military District (BMD) (Szynowski and Zajdziński 1998, p. 384). The territorial scope covered the Kaliningrad Oblast of the RSFSR and the three Baltic republics: the Lithuanian Soviet Socialist Republic (Lithuanian SSR), the Latvian Soviet Socialist Republic (Latvian SSR) and the Estonian Soviet Socialist Republic (Estonian SRR). In terms of organisation of the military system of the state, the region played an important role in the strategic objectives of occupation of north-western Europe by the Army of the Warsaw Pact. Its military importance was underlined by the non-freezing sea ports in the area. Their equipment and coastal infrastructure enabled the reception and combat service of ships of all classes operating in the Baltic Sea. The region includes shipyards where ships can be built and renovated. An extensive network of military airports and an internal rail and road network play an important role. This creates the possibility of an efficient transfer of troops, weapons and equipment, as well as material and technical means. The Baltic was an important sea basin for both NATO and the Warsaw Pact. The Danish straits are of strategic importance for NATO. Their loss would have the effect of breaking the link between Northern Europe and Central Europe. In addition, military control of the Western Baltic coast by the armies of the Warsaw Pact, and then of some of the North Sea coast, threatened the northern wing of NATO's land forces. Land forces stationed in the Oblast were part of the second strategic plan of Soviet troops (Zaccor 1993, p. 29). 
At the beginning of the 1990s, the Kaliningrad Oblast temporarily lost its military importance. Both the general relaxation after the period of rivalry between two blocks and serious internal problems in Russia provided favourable conditions for such a situation. The Baltic Military District was renamed the North-Western Military Group (NWMG). After the reunification of Germany and the regaining of independence by the Baltic republics, the Soviet units stationed there were mostly relocated to the Kaliningrad exclave. As a result, the region became a specific gathering point for Soviet troops withdrawn from Central European countries. These troops were gradually, after being restructured, relocated to other regions. The collapse of the Soviet Union led to a partial disorganisation of the logistic security system and the conditions of military stationing. The number of naval bases and the network of military airports decreased. The material supply system was seriously compromised. The above and the changing circumstances of the European security environment led to a renewed increase in the military importance of the exclave. Military units stationed in the region were operationally subordinated to the commander of the Baltic Fleet. He also became the commander of the Kaliningrad Special Defence Region (KSDR), which was subordinated directly to the Chief of General Staff. This increased its importance in relation to other Military District commanders and naval fleets. It proved the importance of this, in fact, not very numerous, operational relationship exaggeratedly called the fleet. Subordinating all units stationed in the Kaliningrad Oblast to the commander of the Baltic Fleet, a unique command structure, created the Kaliningrad Special Area (KSA). It combined elements of a military system and a non-military subsystem. Such a structure ensured a high degree of autonomy conducting combat activities and guaranteed the protection of national interests in the Baltic Sea Region. With the reorganisation, the character of the maritime component changed from offensive to definitely defensive. This was evidenced by the withdrawal from the line of most large surface vessels, the specific nature of the exercises conducted and the basic tasks consisting in paralysing navigation in the Baltic Sea and blocking the opponent's ports and naval bases.

\section{Quantities}

In the first half of the 1990s, significant changes took place in the number of Russian troops stationed in the Kaliningrad Oblast. There were two reasons for this. Firstly, the collapse of the Soviet Union resulted in the regaining of independence of the Baltic 
republics. As a result, units from Lithuania, Latvia and Estonia were deployed in the Oblast and most of the forces of the Baltic Fleet were concentrated there. The second reason was the dissolution of the Warsaw Pact, which was followed by another concentration due to the withdrawal of Soviet (Russian) troops from the former GDR and Poland. At that time, the Kaliningrad exclave served as a gathering point. Several hundred thousand soldiers and a significant number of combat techniques were deployed there. According to various sources, between 200000 and 300000 soldiers were deployed in the region (Kaliszewicz and Szynowski 2002, p. 109; SIPRI Yearbook 2013... 2013). In 1991, the number of units stationed in the Oblast amounted to 169 000, and in 1992 to approximately 295200 soldiers (Szynowski 2001, p. 151). After 1993, this potential was systematically reduced. Some of the units were demolished and others, after the reorganisation, were relocated to Russia. In 1998, up to 60000 soldiers were stationed in the exclave (Szynowski 1998, pp. 70-71). The process of reduction was so intense that in 1999 it led to a reduction of the personnel by $89 \%$, i.e. to a level of about 32 000 soldiers. In 2000, about 25000 soldiers were stationed in the Kaliningrad Oblast, and in 2010, after changes in the Russian command system, from 12500 thousand to 13000 soldiers (Rosyjskie sity zbrojne... 2017). It is estimated that in 2012, the number of units stationed in the Oblast ranged from 18000 to 25000 soldiers (Galoch 2012, p. 8). Comparing the available information on the number of Russian Armed Forces stationed in the region, it should be noted that there are significant discrepancies. Their number usually ranges from 25000 to 35000 , depending on the source (approximately 25 000, Wiśniewska 2016, p. 17; 30 000-35 000, Obwód Kaliningradzki i Krym... 2017). Analysing the exercises conducted in recent years, it can be assumed that the number of 15 000-20 000 is closer to the truth. Russia's current military capacity should be considered as corresponding to the region's operational capacity.

\section{Basic arms and equipment}

The declining number of troops stationed in the Kaliningrad Oblast resulted in a reduction in the amount of armaments and military equipment in their possession. This process covered all types of armed forces and armies. Due to the nature of the Kaliningrad military component, an analysis of the quantitative status should start with the maritime forces. They include: assault vessels, minesweepers, transport and assault vessels and auxiliary vessels. The number of surface vessels decreased from 202 in 1990 to 36 in 
1999, and of submarines from 47 to 2 (Wiśniewska 2016, p. 17; Obwód Kaliningradzki $i$ Krym... 2017). The reduction, by around $85 \%$, was essentially based on the withdrawal from service of large vessels whose combat capacity in a closed water area such as the Baltic Sea was significantly reduced. A similar situation occurred in two consecutive groups of warships. The minesweeper forces were reduced from 119 units in 1990 to 19 units in 1999, and the assault units from 20 to 5 units; in total, both groups of ships were reduced by more than $82 \%$. The auxiliary units were treated differently. The percentage share of this group of vessels in relation to warships was $20 \%$ in 1990 and $67 \%$ in 1999 , respectively. This was mainly due to the reduction of combat units without the withdrawal of security vessels from service. In view of this trend, it can be assumed that naval forces of the Baltic Fleet lost their previous combat capability. The reduction of the military capacity adjusted it to the actual needs. It should be recognised that in the case of ship assault forces, the qualitative combat potential dominates over the correlated numerical potential (Ficon 1997). In 2000, The Baltic fleet had 99 ships at its disposal (Rosyjskie sity zbrojne... 2017). Following changes in the Russian command system in 2010, the naval forces included, inter alia: 2 destroyers, 2 frigates, 3 corvettes, 4 large assault vessels, 11 missile racers and 4 small ASW vessels (Rosyjskie sity zbrojne... 2017). Currently, the equipment count is 2 underwater and 56 surface combat units, including 2 destroyers, 4 frigates, 2 patrol vessels, 6 missile racers, 6 submarine racers, 6 torpedo boats, 1 escort trawler, 5 base trawlers, 9 red trawlers, 4 large and 2 small assault vessels and 9 assault cutters. The submarines are constructions of the 1980s, of NATO’s Kilo class, with diesel-electric drives.

When considering the armaments of ground troops and shore forces, the quantitative status should be taken into account according to its main types: tanks, armoured fighting vehicles (AFVs), operational and tactical missile launchers, helicopters and artillery systems with a calibre of more than 100 millimetres. Since 1990, the quantity of arms and equipment has been gradually reduced. The largest accumulation of such supplies in the Kaliningrad region was recorded in the years 1992-1994. In 1992, the region was equipped with: 1706 tanks, 2957 AFVs, 1,427 artillery systems and 48 attack helicopters (Szynowski 2001, pp. 159-160). Since 1993, there has been a gradual reduction in the number of weapons. At the turn of 1993 and 1994, the Oblast had: 1230 tanks, around 1470 AFVs, and around 60 attack helicopters (Ogonowski 2000, p. 116). By 1997, the quantitative status of combat technology had been reduced to the following level: 850 tanks, 925 AFVs, 426 artillery systems and 50 helicopters. In 1999, 
there was a slight increase in the number of weapons and equipment in question, with the exception of AFVs, whose number was reduced to 860 (Szynowski 2001, pp. 159-160). In 2000, the armies were equipped with: 816 tanks, 853 AFVs, 345 artillery systems, 20 attack helicopters and 29 auxiliary helicopters (Rosyjskie sity zbrojne... 2017). In 2003, the combat stock included: 811 tanks, 865 AFVs, 345 artillery systems and 41 attack helicopters (The Military Balance 2003-2004, pp. 92-93). It should be noted that the reduction first applied to the armaments and equipment of older designs and years of production (Ogonowski 2000, p. 116). The process was carried out in this way until only new generations of equipment were supplied. In 2010, after changes in the Russian command system, the army stationed in the exclave was equipped with: 811 tanks, 1239 AFVs, 345 artillery systems with a calibre greater than $100 \mathrm{~mm}, 18$ tactical ballistic missiles and 170 aircraft and helicopters (Rosyjskie sity zbrojne... 2017).

The years 1990-1999 were characterised by a significant reduction in the volume of combat equipment of the Air Force stationed in the Kaliningrad Oblast. The largest potential of these types of weapons was accumulated in the years 1991-1992. In 1991, the region lwas home to (or had under the direct control of the Baltic Fleet commander) 585 aircraft, including 540 aircraft and 45 helicopters. A significant reduction in the number of aircraft took place in 1993. This was largely due to the fact that some of the aircraft were relocated to Russia. In 1999, air forces were equipped with 134 flight devices (Szynowski 2001, p. 159-161). In 2003, they were equipped with 55 combat planes (The Military Balance 2003-2004, p. 92). In the years 1990-1999, the fighting equipment of the Air Forces stationed in the exclave was reduced by about 77\% (Rosyjskie sity zbrojne... 2017). The reduction was carried out, as in the case of the land forces, by eliminating, first of all, the equipment of older designs and years of production.

The essential elements of ballistic armaments stationed in the Kaliningrad region are as follows: S-400 Triumf mobile missile sets, Iskander-M systems, Bastion anti-ship sets (including P-800 Oniks missiles), 9K79-1 Toczka-U and 9K79M Toczka-M operational and tactical missile sets, Redut shore defence missile sets, 9K33 Osa and 9K331 Tor-M1 anti-aircraft missile sets and BM-21 Grad launchers. Moreover, the Russian side announced that 3 corvettes of Bujan-M equipped with modern Kalibr-NK manoeuvring missiles would be supplied to the Baltic Fleet. 


\section{Structure and tasks}

The reorganisation of troops stationed in the Kaliningrad exclave carried out in the first half of the 1990s was largely related to the territorial changes and the emergence of new states in the post-Soviet area. The next stage of consolidation of the military potential stationed there was the creation, on 1 December 1997, of the Concentrated Border Forces of the Baltic Fleet (CBFBF), which was subordinated to the Commander of the Fleet. Its integrated air defence system was also set up. The Baltic Fleet included maritime forces, maritime aviation, air defence forces and measures, as well as land forces and coastal defence forces. Units of all kinds of armed forces and troops were subordinated directly to the Fleet Commander. The military structures in the Kaliningrad exclave are divided organisationally into the Baltic Fleet's naval and aviation units and land army units, naval infantry and coastal defence units. The command of the Fleet is stationed in Kaliningrad.

The maritime component is designed to defend Russian maritime areas, ensure compliance with jurisdiction in internal waters, territorial waters and the Russian economic zone, and to protect the country's territory from the sea side (Szynowski 2001, p. 129). Land Forces and Coastal Forces are designed to repel land-air and sea strikes. Their main task is to conduct military operations and, in times of peace, to maintain a certain level of combat readiness and continuous ability to perform the tasks set forth. In the first half of the 1990s, many land military units passed through the Kaliningrad Oblast. This led to a temporary accumulation of significant military capabilities, particularly in the area of arms and military equipment. The population level stabilised at the end of the twentieth century. Together with it, a gradual transition was made from the division structure to the brigade structure. A significant percentage of the land forces stationed in the exclave are armoured and mechanised units, as well as missile artillery and special forces. Another component of the Baltic Fleet is the air component. Its main tasks include (Szynowski 2001, p. 129): air traffic control, air rescue, warning and notifying the army of threats and strikes from the air, fighting for an advantage in the air, fighting against the opponent's surface and shore objects, and air support for land military groups and naval forces. Changes in the structure of the Armed Forces of the Russian Federation and the concept of the Oblast defence have led to the integration of the air defence system. A centralised system for airspace identification and control was set up because of the existing radar stations. Its capabilities are highly appreciated by the Russians, who 
claim that „(...) no air target over England, Germany or anywhere in the Southern Belt is a secret for the air defence of the Baltic Fleet" (Szynowski 2001, p. 132).

At the end of the 1980s, the following land component units, among others, were stationed in the Kaliningrad Oblast: $1^{\text {st }}$ and $40^{\text {th }}$ Armoured Division, $1^{\text {st }}$ and $26^{\text {th }}$ Motorised Riflemen Division, $152^{\text {nd }}$ Missile Brigade, $244^{\text {th }}$ Artillery Brigade, $183^{\text {rd }}$ and 259 $9^{\text {th }}$ Anti-Aircraft Missile Brigade, $689^{\text {th }}$ Missile Artillery Regiment, $710^{\text {th }}$ Artillery Regiment, 993 ${ }^{\text {rd }}$ Anti-Tank Artillery Regiment, 288 ${ }^{\text {th }}$ and $489^{\text {th }}$ Helicopter Regiment, $405^{\text {th }}$ Pilotless Flight Devices Regiment and $87^{\text {th }}$ Mixed Air Squadron (Rosyjskie sity zbrojne... 2017). In addition, there was one air-parachute brigade located there, and the following units of the Air Forces: $689^{\text {th }}$ Air Fighter Regiment, $4^{\text {th }}$ Air Bomber Regiment and 43 $3^{\text {rd }}$ Anti-Aircraft Missile Brigade. In the years 1989-1991 the following maritime aviation units were also stationed there: $846^{\text {th }}$ Assault Air Force, $15^{\text {th }}$ Air Recon Regiment, $75^{\text {th }}$ Mixed Air Regiment and $49^{\text {th }}$ and $145^{\text {th }}$ Mixed Air Squadron.

In 2005, most of the forces of the Baltic Fleet were stationed in the Kaliningrad exclave (Rosyjskie sity zbrojne... 2017). The maritime component included: $128^{\text {th }}$ Surface Ships Brigade, 36 ${ }^{\text {th }}$ Missile Ships Brigade, $71^{\text {st }}$ Assault Ships Brigade and 64 $4^{\text {th }}$ Water Protection Ships Brigade. The coastal units (coastal defence forces) included: $336^{\text {th }}$ Maritime Infantry Brigade, $7^{\text {th }}$ Motorised Riflemen Brigade, $18^{\text {th }}$ and $79^{\text {th }}$ Motorised Riflemen Brigade, $275^{\text {th }}$ Motorised Riflemen Regiment, $152^{\text {nd }}$ Missile Brigade, 244 ${ }^{\text {th }}$ Artillery Brigade and $25^{\text {th }}$ Coast Missile Regiment. The air component consisted of: $4^{\text {th }}$ Air Bomber Regiment, 689 $9^{\text {th }}$ Air Fighter Regiment, 263 ${ }^{\text {rd }}$ Mixed Air Regiment, $125^{\text {th }}$ Helicopter Regiment and $396^{\text {th }}$ ASW Helicopter Squadron. The anti-aircraft forces included the $43^{\text {rd }}$ and $183^{\text {rd }}$ Anti-Aircraft Missile Brigades.

In December 2010, as a result of changes in the command system of the armed forces, KSDR was subordinated, as an independent operational association, to the command of the newly established Western Military District (WMD) ) (Rosyjskie sity zbrojne... 2017). The changes mainly covered the air and land components. The reorganisation of the maritime component has been postponed for financial reasons. The equipment and weapon bases were decommissioned, leaving behind $2574^{\text {th }}$ and $2676^{\text {th }}$ Weapon and War Stock Bases and the $42^{\text {nd }}$ Arsenal of GRAU (ГРАУ - Главное ракетноартиллерийское управление, Main Missile and Artillery Division) (Перечень воинских частей... 2016). Some of the surplus weapons and military equipment was withdrawn from the territory. Most units, including the operational ones, were included in the permanent combat readiness regime. In addition, actions were taken to 
integrate the command system functionally in the conditions of conducting combined operations. The changes concerning the operational grouping of the enclave area were in line with the general direction of the reform of the Russian Federation's Armed Forces. The goal was to optimise military structures in correlation with their tasks. The most important coastal units in the Oblast were: the maritime infantry brigade, motorised riflemen brigade, missile brigade, artillery brigade, motorised riflemen regiment, shore defence missile regiment, two anti-aircraft missile brigades. The aviation component consisted of three units of the regiment-squadron structure.

Currently, the forces (units) deployed in the Kaliningrad exclave can be divided into two parts (Obwód Kaliningradzki i Krym... 2017). The first is subordinated to the Baltic Fleet command. In addition to the surface and underwater naval forces, it also includes shore-based vessels and air forces. The second reports directly to the command of MOU and consists of units of Land Forces, Air Forces and Air and Space Forces. The following naval forces are subject to the Baltic Fleet Command: $128^{\text {th }}$ Surface Ships Brigade, $71^{\text {st }}$ Assault Ships Brigade, 36 $6^{\text {th }}$ Torpedo Boats Brigade, 64 ${ }^{\text {th }}$ Water Protection Ships Brigade with auxiliary units, two naval bases in Baltiysk and Kaliningrad, several bases with auxiliary units (hydrographic, repair, tugboats and others) and coast protection units (engineering, repair, medical, supply, communications, etc.). The land and air components of the Baltic Fleet include: $336^{\text {th }}$ Maritime Infantry Brigade, $313^{\text {th }}$ Special Purpose Baltic Fleet Squad, $4^{\text {th }}$ Air Assault Regiment, $689^{\text {th }}$ Air Fighter Regiment, $398^{\text {th }}$ Air Transport Squadron, $125^{\text {th }}$ Helicopter Squadron and $396^{\text {th }}$ Deck ASW Helicopter Squadron. The Air Force units of the Baltic Fleet are stationed in bases in Chkalovsk, Chernyakhovsk and Donskoye. Most of the Land Force units, including artillery, missile, anti-aircraft and Spetsnaz, are directly under the command of the Western Military District. The most important of these are: $79^{\text {th }}$ Motorised Guard Brigade from Gusev, $7^{\text {th }}$ Motorised Guard Infantry Regiment from Kaliningrad, $152^{\text {nd }}$ Missile Guard Brigade from Chernyakhovsk (equipped with Toczka-U, Toczka-M and Iskander missile systems), $244^{\text {th }}$ Artillery Brigade of Kaliningrad, 25 ${ }^{\text {th }}$ Baltic Sea Missile Regiment, Kaliningrad and Baltiysk-stationed Spetsznaz subdivisions, $3^{\text {rd }}$ Air and Space Force Brigade from Kaliningrad including two missile regiments armed with S-300 systems $\left(183^{\text {rd }}\right.$ one from Gvardeysk and $1545^{\text {th }}$ one from Znamensk) and the $22^{\text {nd }}$ Anti-aircraft Missile Regiment from Kaliningrad equipped with the Tor-M1 system. The ranks of the $3^{\text {rd }}$ Brigade also include extensive radio-electronic recon and electronic combat units as well as the Voronezh-DM (Pionerskoye) radar station, which can detect objects up to 6000 $\mathrm{km}$ away. This station is part of the ballistic missile early warning system. Among other 
subdivisions stationed in the exclave, one should mention: $841^{\text {st }}$ Radioelectronic Warfare Centre, 302 ${ }^{\text {th }}$ Radioelectronic Warfare Regiment, $73^{\text {rd }}$ Pontoon-Bridge Battalion, $142^{\text {nd }}$ Radioelectronic Warfare Battalion, $37^{\text {th }}$ Engineering and Sapper Battalion, $148^{\text {th }}$ Repair Battalion and $1488^{\text {th }}$ Motor Vehicle Battalion.

\section{Training}

The level of tactical-operational and special training is strongly influenced by training and exercises with the army. The intensity of training of units in the Armed Forces of the Russian Federation decreased significantly at the end of the 20th century. This was closely related to political changes in Russia, the limited financial possibilities of the state and costly securing of the process of withdrawal of former units of the Red Army from Central and Eastern Europe. The low military budget was mostly spent on vegetative expenditure. The financial shortfall has particularly affected subdivisions in possession of road and complex military technology. The above had a negative impact on the level of training of troops stationed in the Kaliningrad exclave. This was mainly due to the aforementioned process of withdrawing the units within the Armed Forces of the Russian Federation from the former Soviet republics and Eastern Bloc countries. Securing relocation changes has become a priority task for local units. Until 1997, most of the projects they carried out had basically been this type of activity.

In the first years of the 21 st century, there was a visible improvement in the training of the military. The training directions of individual units were adjusted to the new tasks resulting from the change of geostrategic conditions and the new war doctrine. The specific structure of the Baltic Fleet and its purpose forced the development of an appropriate training mode. It attached great importance to the ability to act autonomously. This trend is due to the fact that the exclave is cut off from the bulk area of the Russian Federation. The units deployed in the Kaliningrad Oblast, due to its isolation, are forced to take into account the issues of conducting independent operational activities and selfsufficiency in terms of combat and logistic security in the training.

The training activity of the Russian army has increased since 2013. It manifests itself in a series of exercises and tests of combat readiness, usually unannounced beforehand. The above situation significantly differs from the typical standards of combat training. The forces and resources involved, the area of activity, the number of exercises and, above 
all, the way they are conducted, set a precedent in the history of the Russian Federation. Increased activity helps tactical teams and units of military type to achieve a state of constant combat readiness. They are able to undertake tasks at a considerable distance from their home bases without long-term and visible preparation. This makes it possible to launch a swift operation on the scale of the Russian-Georgian war. The military potential deployed in the region is perceived differently in terms of combat training. The largest amount of information concerns the Baltic Fleet, which has been systematically trained for many years. This is evident in the area of tactical-operational training, which includes, among other things, combating groups of potential enemy ships (presumably NATO maritime forces), carrying out infantry assaults from the sea and searching for and eliminating submarines. An analysis of military exercises allows us to believe that the land component is equally well prepared for the implementation of military tasks in the Baltic Sea Region. This is evidenced, among other things, by publicly available materials concerning exercises at the battalion-brigade level. Relatively little is known about the preparation and training of missile units, including anti-aircraft and coast defence, and of the aviation component. However, an undeniable fact is that the number of exercises is constantly increasing.

The high level of readiness of the units within the Armed Forces of the Russian federation has been confirmed by extensive exercises with the army. Among the exercises carried out in recent years, we should first mention a series of Russian-Belarusian exercises under the codename „Zapad (West)” (2009, 2013 and 2017). They were attended by units stationed in the area of the Kaliningrad exclave. For example, the scenario of the exercise „Zapad 2009” foresaw fighting off a NATO attack (Sakson 2014, p. 115). The main objective of the Zapad 2013 manoeuvres was the procedures of the Iskander missile system that was relocated to the Kaliningrad Oblast (Sakson 2014, p. 115). It was probably an excuse to launch the process of replacing the obsolete missile armaments. The Zapad 2017 exercise was the culmination of a number of training projects carried out in the western strategic direction (Wilk 2017). Just before it was launched, the engineering subunits of the Baltic Fleet had practiced an attack on the fortified beaches (Rosjanie wysadzili desant... 2017). The soldiers trained in mine planting and antiassault barriers, and then practiced overcoming and destroying them. The missile troops trained in fighting off and performing attacks during the offensive activities of the enemy (Ćwiczenia wojsk rakietowych... 2017). As a part of the exercises, marches from places of permanent dislocation were carried out under the constant threat of air strike and attacks by the enemy sabotage subdivisions. The full cycle of launcher operation was 
practiced, i.e. loading, preparation for activation and simulated launch. At least several dozen different projects were carried out in within MOU. Among them, the following exercises are worth mentioning: mobilisation and raising of readiness levels, relocation changes, regrouping and marching of troops, as well as typical tactical exercises in the training range. They involved all types of troops and services from battalion level to division level. The most important undertakings of the $11^{\text {th }}$ Army Corps, which is stationed in the Kaliningrad Oblast, were: the brigade exercise of the $336^{\text {th }}$ Sea Infantry Brigade from Baltiysk, the regiment exercise of the $7^{\text {th }}$ Kaliningrad Mechanised Regiment and the exercise of $244^{\text {th }}$ Artillery Brigade and $25^{\text {th }}$ Missile Brigade (equipped with Bastion systems operating Kalibr missiles) (Wilk 2017). Most of the units deployed in the District in 2017 underwent several exercises, including the $11^{\text {th }}$ Army Corps four times. Within the framework of the Zapad 2017 manoeuvres, land subdivisions trained in combat activities in urbanised areas (Zapad-2017. Rosjanie... 2017).

The Minister of Defence of Sergey Shoygu, while in Kaliningrad, stressed that there were more than 30 tactical brigade and battalion groups ready to take immediate action westwards (Rosjanie ostrzegaja. „Na... 2017). The Minister stated that these groups had the necessary staff and material equipment. In the last half of the year, MOU received over 300 units of modern weapons and military equipment. Moreover, as the Minister pointed out, the combat training of soldiers is constantly being improved. This is evidenced by more than 100 unannounced tests, which confirmed the high level of the army's combat readiness.

\section{Military infrastructure}

The largest scope of military infrastructure development in the Kaliningrad region took place during the existence of the Soviet Union. This was related to the operational preparation of the East Baltic coast, which was to ensure the independence of activities of Soviet troops stationed in this part of Europe (The Military Balance 2003-2004, pp. 140-141). Political and systemic changes at the turn of the 1980s and 1990s contributed to a significant reduction in the operational area of Russian troops' stationed in the Baltic Sea basin. The number of Baltic Fleet maritime bases and the network of tactical airports decreased. This led to a deregulation of the material supply system. The collapse of the Soviet Union and the consequent loss of the Baltic military infrastructure located 
in the territories of Lithuania, Latvia and Estonia contributed to the resurgence of the military importance of exclave.

The military infrastructure of the Kaliningrad region includes sea bases, airports and landing pads, as well as barracks, supply, medical and repair infrastructure. Marine bases are located in the Baltic Sea and Kaliningrad. They combine to form a port complex that allows for the permanent accommodation of about 160 medium and small ships. Most of the air bases are located in the western part of the exclave. The most important of these are: Chkalovsk, Chernyakhovsk, Pravdinsk and Nivienskoye. There are also elements of the air traffic recon and control system in this area, including approach control radar in Kaliningrad and area control radar in Chernyakhovsk (The Military Balance 2003-2004, p. 142). As a result of territorial changes, Russia lost most of its Baltic coastline after 1991. This limited the capabilities of the radar recognition and notification system for air defence forces and means. Currently, the system consists of stations located in Baltiysk, Donskoye, Primorsk and Yantarne (on the Taran peninsula). The infrastructure of the onshore component is distributed throughout the whole area of the Oblast. Its greatest saturation occurs in the southern part, between the Pregola River and the border with Poland. Large sets of barracks are located in Mamonovo, Komievo, Dolgorukovo and Chernyakhovsk.

Geostrategic changes in the Baltic Sea basin disturbed the cohesion of the Armed Forces of the Russian Federation's supply system stationed in the Kaliningrad Oblast. The main reason for this was the emergence of new states, whose territories have separated the Oblast from the bulk territoryofRussia.Deliveriesofsuppliesrequiretransit, whichincreasestheroleandtasksofseaand air transport (Stadtmuller 2003, pp. 154-155 and 160). The accumulation of transit problems contributed to considerable difficulties in the supply of troops. This has led to a restructuring of the existing system and its adaptation to the new situation. In the Kaliningrad exclave, the repair base functions well. It enables all types of repairs and maintenance to be carried out and the weapons and military equipment used by local units to be upgraded. The land forces have two repair battalions and $6454^{\text {th }}$ Repair Base. Additionally, the tasks within the scope of military armaments and equipment repair are performed by the Renovation Plants in Kaliningrad and the renovation base in Chernyakhovsk. Repairs to aviation technology are carried out in the Renovation Plants in Svetly and in the Technical Airbase in Donskoye. There are three shipyards which build surface ships and are able to repair most of the surface vessels of the Baltic Fleet. 


\section{Conclusion}

The collapse of the Eastern Bloc and the USSR led to the withdrawal of Russian troops from Central and Eastern Europe. They were largely redeployed to the Kaliningrad Oblast between 1991 and 1995. This led to the excessive and unreasonable, from a security perspective, concentration of military capabilities on its territory. Since 1993, there has been a systematic reduction in the personnel status of units stationed in the exclave. At the same time, the amount of weapons and military equipment was reduced. The reduction concerned, in the first place, armaments of the oldest designs and years of production. The greatest accumulation of military potential took place in 19921994, when its systematic reduction resulted partly from political commitments and declarations, signed international agreements, and partly from the limited economic capacity of the Russian Federation. The changes described above led, in 1997, to the formation of an optimal structure of the Baltic Fleet stationed in the Kaliningrad Oblast. It consisted of naval forces, land and shore units, and air forces. Since 2010, a separate land component has been stationed in the area of the exclave, independent of the Baltic Fleet commander. It reports directly to the commander of the Western Military District. With the doctrinal changes, the military importance of the Kaliningrad Oblast has been gradually increasing. Equipped with modern missile systems, it has become a demonstration site for power, used periodically in political games with the West.

Following the difficulties connected with relocating and restructuring the Armed Forces, the system of military training stabilised. It has been adapted to the new structures and to the tasks that have been assigned to them. Its intensity and, consequently, the effects achieved, depend, to a large extent, on Russia's current economic opportunities. It is estimated that Russian Armed Forces have a level of operational capability that allows them to carry out military tasks in the post-Soviet area with relative ease. This is evidenced by the relatively large number of units of various types of troops that have achieved a high level of combat readiness. This is confirmed by the results of exercises with the army and unannounced tests of combat readiness, which are more and more frequently carried out with the participation of the units stationed in the exclave. It is assumed that they are capable of effectively blocking the Baltic coast and that when supported, they can carry out aggressive operations themselves.

The unannounced tests of combat readiness that are often carried out with the participation of units stationed in the Kaliningrad Oblast are, to a large extent, 
a demonstration of strength with regard to neighbours and to the EU and NATO. In the public perception, they prove that the reforms are advisable and effective. This is particularly important in view of the slowdown in economic growth and the consequent need to seek budgetary savings. The publicity given to some of the training projects carried out allows us to believe that Russia is building an atmosphere in which a military threat from the West is felt its society. This should also be seen in the context of justifying further increases in defence spending, including an increase in the number and operational capacity of the units deployed in the Kaliningrad Oblast. In the coming years, despite the economic crisis, Russia will modernise the Armed Forces stationed in the exclave. Broadly understood preparations of conventional forces to respond to asymmetric threats, particularly in the immediate vicinity, will continue.

\section{Literary references}

Ćwiczenia wojsk rakietowych $w$ Kaliningradzie, 2017 [online] Available from: http://www. defence24.pl/199761,cwiczenia-wojsk-rakietowych-w-kaliningradzie [Accessed 17 Mar 2018].

Eberhardt, P., 1996. Między Rosja a Niemcami. Przemiany narodowościowe w Europie ŚrodkowoWschodniej $w X X$ w. PWN, Warszawa.

Eberhardt, P., 1994. Obwód Kaliningradzki. Wczoraj, Dziś, Jutro, Przeglad Wschodni, 3(4).

Ficoń, K., 1997. Analiza potencjałowa sił okrętowych państw bałtyckich, cz. I, Flota Bałtycka, Przegląd Morski, 6.

Galoch, B., 2012. Kaliningradzki Rejon Specjalny a tarcza przeciwrakietowa, Przegląd Sit Powietrznych, 1.

Kaliszewicz, P. and Szynowski, R., 2002. Obwód Kaliningradzki w systemie militarnym Rosji. In B. Fijałkowska and A. Żukowski (eds), Unifikacja i różnicowanie się współczesnej Europy, Dom Wydawniczy Elipsa, Warszawa.

Obwód Kaliningradzki i Krym czyli ufortyfikowane twierdze Rosji, 2017 [online] Available from: https://oaspl.org/2016/01/28/obwod-kaliningradzki-i-krym-czyli-ufortyfikowane-twierdzerosji/ [Accessed 18 Mar 2018].

Ogonowski, A., 2000. Perspektywy rozwoju Obwodu Kaliningradzkiego, Przeglad Wojsk Lądowych, 7.

Palmowski, T., 2013. Kaliningrad - szansa czy zagrożenie dla Europy Battyckiej?, Wydawnictwo „Bernardinum”, Gdańsk-Pelpin.

Rogoża, J., Wierzbowska-Mizgała, A. and Wiśniewska, I., 2012. Wyspa na uwięzi. Kaliningrad między Moskwą a UE, Prace OSW, 41.

Rosjanie ostrzegaja. „Na zachodzie kraju mamy 30 grup taktycznych w gotowości bojowej”, 2017 [online] Available from: https://wiadomosci.wp.pl/rosjanie-ostrzegaja-na-zachodzie-krajumamy-30-grup-taktycznych-w-gotowosci-bojowej-6136023472023681a [Accessed 19 Mar 2018]. 
Rosjanie wysadzili desant na plażach Battyku. Manewry tuż przy polskiej granicy, [online]. Available from: https://wiadomosci.wp.pl/rosjanie-wysadzili-desant-na-plazach-baltyku-manewry-tuzprzy-polskiej-granicy-6160044019476609a [Accessed 20 Mar 2018].

Rosyjskie sity zbrojne $w$ Kaliningradzie, [online] Available from: http://dziennikzbrojny.pl/ artykuly/art, 2,6,6819, armie-swiata,potencjal,rosyjskie-sily-zbrojne-w-kaliningradzie [Accessed 21 Mar 2018].

Sakson, A., 2014. Obwód Kaliningradzki a bezpieczeństwo Polski, Przeglad Strategiczny, 7.

Sawicki, K., 2013. Obwód Kaliningradzki FR $w$ tadzie międzynarodowym, Dom Wydawniczy DUET, Toruń.

SIPRI Yearbook 2013: Armament, Disarmament and International Security, 2013. Oxford University Press, Oxford.

Skrzyp, J. and Lach, Z., 1997. Obwód Kaliningradzki-charakterystyka wojskowo-geograficzna, Wydawnictwo AON, Warszawa.

Stadtmuller, E., 2003. Pożegnanie z nieufnością? Rozszerzenie NATO i UE a stosunki polsko-rosyjskie $w$ kontekście bezpieczeństwa europejskiego, Wydawnictwo Uniwersytetu Wrocławskiego, Wrocław.

Szynowski, R., 2001. Obwód Kaliningradzki w systemie militarnym Rosji, Rozprawa doktorska, AON, Warszawa.

Szynowski, R., 1998. Siły zbrojne Rosji w Obwodzie Kaliningradzkim, Przeglad Morski, 4.

Szynowski, R. and Zajdziński, W., 1998. Miejsce i rola Obwodu Kaliningradzkiego w systemie bezpieczeństwa Federacji Rosyjskiej. In W. Wróblewski (ed.), Dziatania militarne w Prusach Wschodnich, Wojskowy Instytut Historyczny, Warszawa.

The Military Balance 2003-2004.

Wilk, A., 2017. Cwiczenia Zapad-2017-wojna (na razie) informacyjna, [online] Available from: https:/www.osw.waw.pl/pl/publikacje/komentarze-osw/2017-09-04/cwiczenia-zapad2017-wojna-na-razie-informacyjna [Accessed 22 Mar 2018].

Wrzesiński, W., 1992. Spór o los Prus Wschodnich (1939), Borussia, 1.

Zaccor, A., 1993. The Baltic States and Kaliningrad: A Briefing, Conflict Studies Research Centre, Kansas City.

Zapad-2017. Rosjanie ćwiczq w obwodzie kaliningradzkim. Trenuja walki w warunkach miejskich, 2017 [online]. Available from: https://wiadomosci.wp.pl/zapad-2017-rosjanie-cwicza-wobwodzie-kaliningradzkim-trenuja-walki-w-warunkach-miejskich-6167522731923073a [Accessed 23 Mar 2018].

Перечень воинских частей Калининграда и Калининградской области, 2016 [online] Available from: http://voinskayachast.ru/goroda/kaliningrad-i-kaliningradskaya-oblast [Accessed 30 Mar 2018].

\section{Author:}

\section{Marek Żyła, PhD}

Faculty of Military Studies, War Studies University, Warsaw, Poland (D) https://orcid.org/0000-0001-7848-0647 